ОТРОКОВ Олег Юрьевич - кандидат политических наук, доцент кафедры экономической теории Ростовского государственного экономического университета (РИНХ) (344002, Россия, г. Ростовна-Дону, ул. Большая Садовая, 69, otrokovoleg@mail.ru)

\title{
СПЕЦИФИКА ДЕЯТЕЛЬНОСТИ НЕКОММЕРЧЕСКИХ ОРГАНИЗАЦИЙ РОССИИ В НАПРАВЛЕНИИ ПОЛИТИЧЕСКОЙ СОЦИАЛИЗАЦИИ МОЛОДЕЖИ
}

\begin{abstract}
Аннотация. В статье проводится анализ специфики деятельности некоммерческих организаций России, их роли и направлений воздействия на политическую социализацию молодежи в двух измерениях: с точки зрения потребностей самой молодежи и возможностей НКО. Автор представляет результаты исследований политического активизма молодых людей, рассматривает направления и условия перехода молодежи из объекта в субъект молодежной политики посредством участия в деятельности НКО. В исследовании потенциал НКО рассматривается в рамках трансформации протестных настроений молодежи в конструктивное политическое участие.
\end{abstract}

Ключевые слова: некоммерческие организации, молодежь, политическая социализация, протестный потенциал

Исследование выполнено при финансовой поддержке РФФИ и ЭИСИ в рамках научного проекта № 20-011-32066\20.

$\mathrm{O}$ дним из важнейших показателей развития гражданского общества выступает активность некоммерческих (неправительственных) организаций. Число организаций, направления работы, объем и качество поддержки со стороны государства, активность участия в их деятельности граждан - все это далеко не исчерпывающий перечень показателей, по которым можно судить о развитии институтов гражданского общества.

Участие молодежи в деятельности НКО не только занимает свободное время и создает условия для проведения содержательного досуга, но и позитивно влияет на факторы социализации, а в зависимости от типа организации - и на первичную подготовку к политической деятельности. В рамках деятельности НКО молодежь может переходить из объекта в субъект молодежной политики, реализуя социальные проекты и определяя векторы развития организации, решая проблемы молодежного сообщества в рамках заданных направлений. Связано это с самой структурой деятельности НКО и механизмами ее управления. НКО выполняют важную социально-политическую функцию, выступая в роли института политической социализации и политического воспитания молодежи, формирования политических предпочтений и ценностей как основы политической картины мира и национально-государственной идентичности российской молодежи [Зиненко и др. 2019: 67].

Основу исследования специфики деятельности некоммерческих организаций в направлении политической социализации молодежи составляет анализ вовлеченности молодежи в работу НКО (через волонтерскую деятельность, участие в мероприятиях и проектах); данных о функционировании молодежных организаций с политической повесткой; результатов социологических исследований различных аспектов политического участия молодежи.

В целом НКО, работающие с молодежью, стоит разделить на два больших блока - имеющие государственную регистрацию и работающие без нее. 
В отечественном законодательстве «молодежность» некоммерческих организаций определяется достаточно размыто. В федеральном законе «О некоммерческих организациях» ${ }^{1}$ молодежные организации как отдельная категория не выделены, что создает неопределенность в установлении юридического статуса таких организаций и механизмах их поддержки. Отсутствует четкое определение отнесения организации к молодежной и в федеральном законе «О государственной поддержке молодежных и детских общественных объединений» 2 . В настоящее время сложилась определенная практика в региональном законодательстве о молодежной политике, либо о поддержке $\mathrm{HKO}^{3}$. Рассмотренные подходы можно сгруппировать и представить в виде двух условий, которые позволяют определить молодежную либо детскую некоммерческую организацию: это, во-первых, возраст членов до 30 либо 35 лет; и, во-вторых, основная либо одна из целей деятельности организации охватывает различные направления работы с молодежью. Самым очевидным и важным фактором, который дополняет два предыдущих либо выступает самостоятельным, является наименование организации, которое содержит предмет ее деятельности, т.е. слова «молодежная», «детская».

В связи с тем, что для классификации НКО в качестве молодежной требуется проведение анализа ее уставных документов, представляется сложным объективно определить число молодежных и детских общественных объединений, действующих в России. По данным реестра Министерства юстиции, в России зарегистрированы более 218 тыс. НКО (в 2016 г. - 223 тыс.). По сведениям региональных общественных палат, число активно работающих НКО не превышает 15-20\% их общего числа 4 . При поиске молодежных организаций на информационном портале Министерства юстиции со словом «молодежь» в наименовании организации (в различных формах) определяется $3955 \mathrm{HKO}$, со словом «детская» - 5180 (включая и детско-молодежные организации) ${ }^{5}$. Соответственно, в полной мере молодежных и детских общественных организаций в общей массе чуть больше $4 \%$, а учитывая заявленную оценку активности НКО по результатам исследования Общественной палаты России, можно констатировать активную работу лишь каждой 4-й молодежной организации (чуть больше 2,2 тыс.). Однако даже этого числа может быть вполне достаточно при условии активной деятельности, большой вовлеченности молодежи и географии реализации проектов.

Общественные объединения, не имеющие государственной регистрации, обычно не так многочисленны, как некоммерческие организации, зарегистрированные в качестве юридического лица, но имеют достаточно разветвленную

\footnotetext{
1 Федеральный закон от 12.01.1996 № 7-Ф3 «О некоммерческих организациях». Доступ: http://www.consultant.ru/document/cons_doc_LAW_8824/(проверено 19.03.2021).

2 Федеральный закон от 28.06.1995 № 98-Ф3 «О государственной поддержке молодежных и детских общественных объединений». Доступ: https://base.garant.ru/103544/ (проверено 19.03.2021).

3 Областной закон Ростовской области «О государственной молодежной политике в Ростовской области» от 25.12.2014 № 309-3С, ст. 2; закон Республики Коми «О молодежной политике в Республике Коми» от 04.10.2010 № 115-Р3, ст. 2; областной закон Ленинградской области «О государственной молодежной политике в Ленинградской области» от 13.12.2011 № 105-о3, ст. 2; закон Краснодарского края «О государственной молодежной политике в Краснодарском крае» от 04.03.1998 № 123-К3 и др.

4 Ежегодный доклад Общественной палаты РФ «О состоянии гражданского общества в Российской Федерации за 2019 год». Доступ: https://www.oprf.ru/documents/1151/2616/ (проверено 19.03.2021).

${ }^{5}$ О деятельности некоммерческих организаций. - Информационный портал Министерства юстищии РФ. Доступ: http://unro.minjust.ru/NKOs.aspx (проверено 19.03.2021).
} 
сеть. Всего в России по состоянию на 01.01.2017 действовали 80064 детских и молодежных общественных объединений, работающих по направлениям государственной молодежной политики (включая зарегистрированные НКО) [Бегичева и др. 2017: 90].

Работа всех молодежных НКО позволяет охватить мероприятиями более 41,3 млн молодых людей [Бегичева и др. 2017: 92]. Учитывая численность молодежи, а также возможности участия одного молодого человека сразу в нескольких мероприятиях и деятельности нескольких организаций, в любом случае можно констатировать высокую степень охвата молодежи.

Основные функции НКО, которые в данном исследовании подлежат анализу, - это не просто реализация социальных проектов и программ, но и переход молодежи в рамках работы НКО из субъекта в объект молодежной политики, а также факторы, влияющие на снижение уровня протестных настроений через активизацию участия в общественно значимой деятельности. Молодое поколение в целом обладает гибким восприятием системы ценностей и умением их трансформировать, а в условиях вовлеченности в глобальные информационные потоки также способно не только воспринимать, но и самостоятельно воспроизводить ценностные ориентиры, обусловливающие дальнейший выбор его социально-экономического и общественно-политического поведения [Пырма 2017: 48]. Эта особенность может проявляться во многих направлениях работы НКО.

Высшим органом управления любой некоммерческой организации является общее собрание членов, соответственно, каждый может в определенной степени влиять на вектор развития, а вхождение в руководящие органы позволяет более направленно реализовывать уставные цели согласно своим представлениям. В данном случае очевидно, что НКО влияют на настроения молодежи и степень ее политического активизма. Влияние может оказываться в различных направлениях и иметь разную степень интенсивности в зависимости от специфики работы, целей и задач деятельности организации.

Молодежные организации реализуют различные программы и проекты, в т.ч. по созданию социальных служб, бирж труда, развитию детского и молодежного предпринимательства, спорта, выявлению и поддержке молодых талантов, национально-культурному возрождению, летнему отдыху, решению жилищных проблем и т.д. [Астафьев 2012: 6]. Вопросы политического участия в общей массе направлений работы НКО достаточно слабо представлены - в этом видится большой потенциал и возможность дальнейшего развития. Вся политическая активность НКО сводится к единичным малочисленным уличным пикетам, митингам либо акциям по отдельным актуальным политическим темам, оппозиционным заявлениям.

За последние годы можно констатировать позитивную динамику участия россиян всех возрастов в деятельности некоммерческих организаций. В 2013 г. $3 \%$ россиян считали себя волонтерами, в 2019 г. этот показатель составлял уже $17 \%$, а каждый третий имел опыт волонтерской деятельности. Почти все население страны (88\%) одобряет волонтерскую деятельность ${ }^{1}$. Этому способствовало проведение больших международных спортивных соревнований, молодежных мероприятий (в т.ч. Всемирного фестиваля молодежи и студентов) на территории России, реализация мероприятий Года добровольца в 2018 г. и др. Важным элементом развития системы добровольчества стало принятие в 2019 г. Концепции содействия развитию добровольчества (волонтерства) в

\footnotetext{
1 Ежегодный доклад Общественной палаты РФ «О состоянии гражданского общества в Российской Федерации за 2019 год».
} 
Российской Федерации до 2025 года. Волонтерство и гражданская активность становятся популярным трендом в молодежной среде, что показывают проведенные социологические исследования.

Левада-Центр в 2019 г. проводил общероссийский репрезентативный опрос населения страны в возрасте 16-34 лет, проживающих в 15 городах-миллионниках. Были опрошены 1014 чел., погрешность не превышала 3,4\%. Как показывают данные опроса, к волонтерству наиболее склонны молодые люди в возрасте 16-20 лет. В среднем во всех исследуемых возрастных группах имели опыт работы волонтерами почти $21 \%$ опрошенных ${ }^{1}$.

Россияне в целом приветствуют идею активно вовлекать молодых людей в общественную и политическую жизнь (так считают около 90\% опрошенных), однако сами молодые люди проявляют меньшую заинтересованность, чем старшее поколение, - такие выводы можно сделать по результатам опроса, проведенного ВЦИОМом в 2017 г. $^{2}$

Что касается участия молодежи в политической деятельности, то в разных исследованиях можно увидеть различные показатели. Так, в опросе, проведенном фондом Фридриха Эберта в 2019 г., только $1 \%$ заявили об участии в политике, $7 \%$ с удовольствием стали бы участвовать, $28 \%$ возможно принимали бы участие, остальных политическая деятельность не интересует совершенно ${ }^{3}$. Исследование Государственного университета управления, проведенное в 2017 г., показало иную динамику показателей: 3,9\% лично участвовали в политической деятельности, 16,5\% внимательно следили за информацией в сфере политики, 48,9\% интересовались политикой от случая к случаю, а 30,7\% политикой не интересовались. При этом членом политической партии или организации уже являлись 2,4\% опрошенных, 22,2\% хотели бы включиться в эту деятельность, остальные не определились либо не имеют желания [Бегичева и др. 2017: 36]. Исследование ВЦИОМа 2017 г. показало, что молодежь практически всех возрастов считает политику сферой, в которой они чаще всего сталкиваются с нарушением ценностей. Молодежь в возрасте 29-34 лет наиболее остро ощущает такие явления 4 .

Участие в деятельности общественных организаций, связанных с политикой, среди других видов политической активности для молодежи стоит на 3-м месте после голосования на выборах и обсуждения политики в частных беседах. Участие же в деятельности политических партий в этом аспекте - лишь на 6-м месте по значимости 5 .

Спектр молодежных политических организаций представляет собой крайне узкую прослойку среди всего перечня НКО. Здесь прежде всего следует выделить организации, работающие как молодежные отделения политических партий, и молодежные политические организации. Среди общего числа обще-

\footnotetext{
1 Исследование Левада-Центра «Гражданский активизм российской молодежи». 2019 г. Доступ: https://www.levada.ru/2020/10/01/grazhdanskij-aktivizm-rossijskoj-molodezhi/ (проверено 19.03.2021).

2 Молодежь и политика: точки соприкосновения. - ВЦИОМ. Доступ: https://infographics. wciom.ru/theme-archive/politics/internal-policy/state-institutions/article/molodezh-i-politikatochki-soprikosnovenija.html (проверено 19.03.2021).

3 Результаты молодежного исследования фонда Фридриха Эберта «Российское «Поколение Z»: установки и ценности». 2019 г. Доступ: https://www.fes-russia.org/ pokolenie-z/ (проверено 19.03.2021).

4 Молодежь и политика: актуальные вызовы. С. 7. Доступ: https://www.wciom.ru/ fileadmin/file/reports_conferences/2017/2017-05-22_cennosti.pdf (проверено 19.03.2021).

5 Молодежь и политика: точки соприкосновения. - ВЦИОМ. Доступ: https://wciom.ru/ analytical-reviews/analiticheskii-obzor/molodezh-i-politika-tochki-soprikosnoveniya (проверено 19.03.2021).
} 
российских НКО таких форм с разной степенью интенсивности работают не больше пары десятков. Наиболее крупные и известные - «Молодая Гвардия Единой России», Всероссийская молодежная организация ЛДПР, Ленинский коммунистической союз молодежи Российской Федерации, молодежное «Яблоко» и ряд других. Такая скромная численность может говорить о низкой степени идеологизации молодежного движения при в целом высоком уровне интереса к политике и волонтерской деятельности. Тенденция отсутствия политической идеологии в деятельности НКО прослеживается не только в нашей стране, но и в международном молодежном движении. Это приводит к снижению негативного влияния идеологических факторов в работе НКО [Деточенко, Пупыкин 2016: 54], но в то же время может способствовать повышению уровня политического нигилизма у молодежи.

По данным официальных сайтов крупнейших молодежных политических организаций, их суммарный охват молодежи не превышает 300 тыс. чел. Учитывая, что число активных членов организаций может быть значительно ниже официально заявленного, можно констатировать крайне низкую реальную вовлеченность молодежи в деятельность молодежных политических организаций. Однако участие в мероприятиях, проектах и политических акциях не требует вступления в ряды организации и может происходить ситуативно в зависимости от проблематики мероприятия. Необходимо также рассматривать возможность молодежи от 18 лет вступать в ряды политических партий напрямую, не работая в молодежных организациях. Такие направления более применимы для «старшей» молодежи - в возрасте от 25 лет, тогда как большинство студенческой молодежи начинают свой политический путь именно в молодежных НКО и органах молодежного самоуправления.

В этой связи можно вывести несколько закономерностей. Во-первых, общественную активность и волонтерскую деятельность молодежь связывает более с социальными аспектами нежели с участием в политических процессах. Эту тенденцию подтверждают опросы, представленные в работе, где виден большой процент вовлеченности волонтеров, но низкий охват молодежных политических организаций. Во-вторых, молодежь не стремится активно заявлять свои политические позиции и становиться членами молодежных политических организаций, хотя достаточно активно готова принимать участие в их мероприятиях. В-третьих, активность НКО, предоставляемые возможности мотивации и их политическая повестка не привлекают молодежь в достаточной степени.

\section{Список литературы}

Астафьев Д.А. 2012. Молодежные движения России: история и современность: курс лекций. Оренбург: ИЦ ОГАУ. 176 с.

Бегичева О.Л., Гришаева С.А., Поляков М.Б., Тимохович А.Н., Чуев С.В. 2017. Ценностные ориентации российской молодежи и реализация государственной молодежной политики: результаты исследования: коллективная монография. М.: ИД ГУУ. $131 \mathrm{c.}$

Деточенко Л.С. Пупыкин Р.А. 2016. Национальные модели молодежной политики: зарубежный опыт: монография. Ростов н/Д: Изд-во ЮФУ. 174 с.

Зиненко В.Е., Карпова В.В., Орлова В.В., Плешаков В.А., Попова С.Ю., Прокохина М.И., Пронина А.А., Пронина Е.В., Селезнева А.В., Чуев С.В., Шилина И.Б. 2019. Государственная молодежная политика в России: социальнопсихологические основания и технологии реализации. М.: Аквилон. 448 с.

Пырма P.В. 2017. Восстание поколения Z: новые политические радикалы. Гуманитарные науки. Вестник Финансового университета. Т. 7. № 2. С. 43-50. 
OTROKOV Oleg Yur'yevich, Cand.Sci. (Pol.Sci.), Associate Professor of the Chair of Economic Theory, Rostov State University of Economics (69 Bolshaya Sadovaya St, Rostov-on-Don, Russia, 344002; otrokovoleg@mail.ru)

\title{
THE SPECIFICS OF ACTIVITIES OF NON-PROFIT ORGANIZATIONS IN RUSSIA IN THE DIRECTION OF POLITICAL SOCIALIZATION OF YOUTH
}

\begin{abstract}
The article analyzes the specifics of the activities of non-profit organizations in Russia, their role and directions of influence on the political socialization of young people in two dimensions: the needs of young people and the possibilities of NGOs. The article presents the results of studies of the young people's political activism, and considers directions and conditions for the transition of young people from an object to a subject of youth policy through participation in the activities of NGOs. The study considers the potential of NGOs within the framework of the transformation of protest moods of youth into constructive political participation.

Keywords: non-profit organizations, youth, political socialization, protest potential
\end{abstract}

